\title{
Challenges of developing a takäful retirement annuity plan in Malaysia
}

Younes Soualhi

\author{
Research Affairs Department, International Shari'ah Research Academy for \\ Islamic Finance, Lorong University, Kuala Lumpur, Malaysia
}

\section{takāful \\ retirement annuity plan}

Received 1 March 2017 Revised 18 March 2017 Accepted 20 March 2017

\begin{abstract}
Purpose - This paper aims to explore the challenges facing the development of a takâful retirement annuity plan in Malaysia. It also aims at exploring a new platform to re-launch the same product after being withdrawn from the Malaysian annuity market a few years ago.

Design/methodology/approach - The research adopts a qualitative approach to address the possible challenges hindering the development of a takâful retirement annuity plan in Malaysia. The research will not discuss the Sharī'ah issues deemed settled in previous researches but will only focus on technical challenges related to the instruments of investment and prudential measures.

Findings - The research found that various challenges face the development of a takafful annuity plan in Malaysia. Some of those challenges are the downsizing of the sukūk market, the shortage of long-term șkūk, longevity risk and risk-based capitalization. The research found that there is a need for a diversified portfolio of securities instead of solely using $s u k \bar{u} k$ as an investment instrument in this product.

Originality/value - Re-launching the takäful annuity plan in Malaysia requires the identification of actual challenges facing the development of such a product. The product purported to be re-launched would benefit a large segment of retirees who do not have enough savings during the retirement age. The introduction of such a product will also expand the takāful market in annuities, which remains untapped.
\end{abstract}

Keywords Takāful, Retirement annuity plan, Longevity risk, Șukūk

Paper type Research paper

\section{Introduction}

Annuities have long been perceived as back-up financial plans during retirement age and a means to reduce longevity risk when an individual outlives his/her assets. The annuitant seeks to secure steady payouts during retirement age by trading liquid lump sums in return for a series of payments until he/she passes away. The product can also include riders such as death benefits or a combination between fixed and variable annuities to protect against the shortfall of investing the annuity fund. The product, which is sold by life insurance and investment companies, passes through two phases: an accumulation phase followed by an annuitization phase. During the accumulation phase, the contributions of the annuitants are accumulated, and the annuity fund is invested in long-term bonds with variant exposure to market risk. During the annuitization phase, the stream of payments during retirement is

(C) Younes Soualhi. Published in the ISRA International Journal of Islamic Finance. Published by Emerald Publishing Limited. This article is published under the Creative Commons Attribution (CC BY 4.0) licence. Anyone may reproduce, distribute, translate and create derivative works of this article (for both commercial and non-commercial purposes), subject to full attribution to the original publication and authors. The full terms of this licence may be seen at http://creativecommons.org/ licences/by/4.0/legalcode

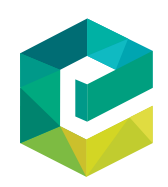

ISRA International Journal of Islamic Finance Vol. 9 No. 1, 2017 9 No. 1,2017
pp. $95-99$ 
made. The different types of annuities - such as fixed, variant, guaranteed and joint - have helped the market to cater for the needs of annuitants and their heirs before and after retirement age (Alhabshi et al., 2012).

takäful markets such as Malaysia's have sought to develop a Sharī'ah-compliant annuity product serving the same objective sought by a conventional annuity, i.e. guaranteeing a stream of payments during retirement age with available riders to secure death benefits. In 1999, Malaysia launched the first Shari'ah-compliant annuity plan dubbed Employment Provident Fund (EPF) takâful Annuity Scheme (SATK) (Yusof et al., 2011). Although the product was widely received by the industry and employees, it was withdrawn in 2002 due to pricing and risk-based capital (RBC) requirements, among other reasons (Ismail, 2017). Some institutions such as Amanah Raya offered a Sharī'ah-compliant Public Mutual Private Retirement Scheme (PRS) that invested the contributions in both sukūk and stocks as a strategy to diversify returns in view of the volatility of the stock market. HSBC Amanah offered a non-guaranteed annuity up to the age of 75 years (Ismail, 2017). By and large, this product was offered under the PRS, which insurance companies, takäful operators, banks and unit trusts are permitted to offer.

The International Sharī'ah Research Academy for Islamic Finance in collaboration with Prudential BSN takäful came up with the conceptual framework and structure for a Sharī'ah-compliant model of a retirement annuity plan (Ali et al., 2014). The paper discussed the potential Sharī'ah issues arising in the proposed model and highlighted some challenges of introducing the takâful annuity plan in Malaysia.

The current paper explores the possibility of relaunching the annuity retirement plan in Malaysia. It particularly seeks to address the key operational challenges in view of previous practices and input from industry players as well as research findings on annuities in Malaysia.

\section{Proposed Sharī'ah-compliant model for retirement annuity plan}

Ali et al. (2014) proposed wakälah (agency) and hibah mu'allaqah (conditional gift) as the underlying concepts for offering a Sharī ah-compliant retirement annuity plan. The wakālah concept is used to manage and invest the annuity fund until the retirement age (i.e. during the accumulation period). This will be followed by hibah mu'allaqah whereby the contributions and the profits arising from the investment of the annuity fund will be donated to the tabarru (donation) fund to start the annuitization stage. The tabarru' fund is used to make the stream of payments during retirement (i.e. retirement payout) and to pay the death benefits (i.e. death payout). Figure 1 depicts the mechanics of the proposed product.

After establishing the Sharī'ah compliance of the model, Ali et al. (2014) identified șukūk as a potential investment instrument during the accumulation period. Citing longevity risk and lack of investment instruments as potential challenges, the paper recommends issuance of more long-term or perpetual government șukūk.

\section{Research objectives}

The current research aims to achieve the following objectives:

- to unveil the potential market of takāful retirement plan in Malaysia;

- to identify the main challenges facing the development and the launching of takāful annuity plan in Malaysia;

- to explore the possible synergy between the takāful industry and the sukūk market in Malaysia; 


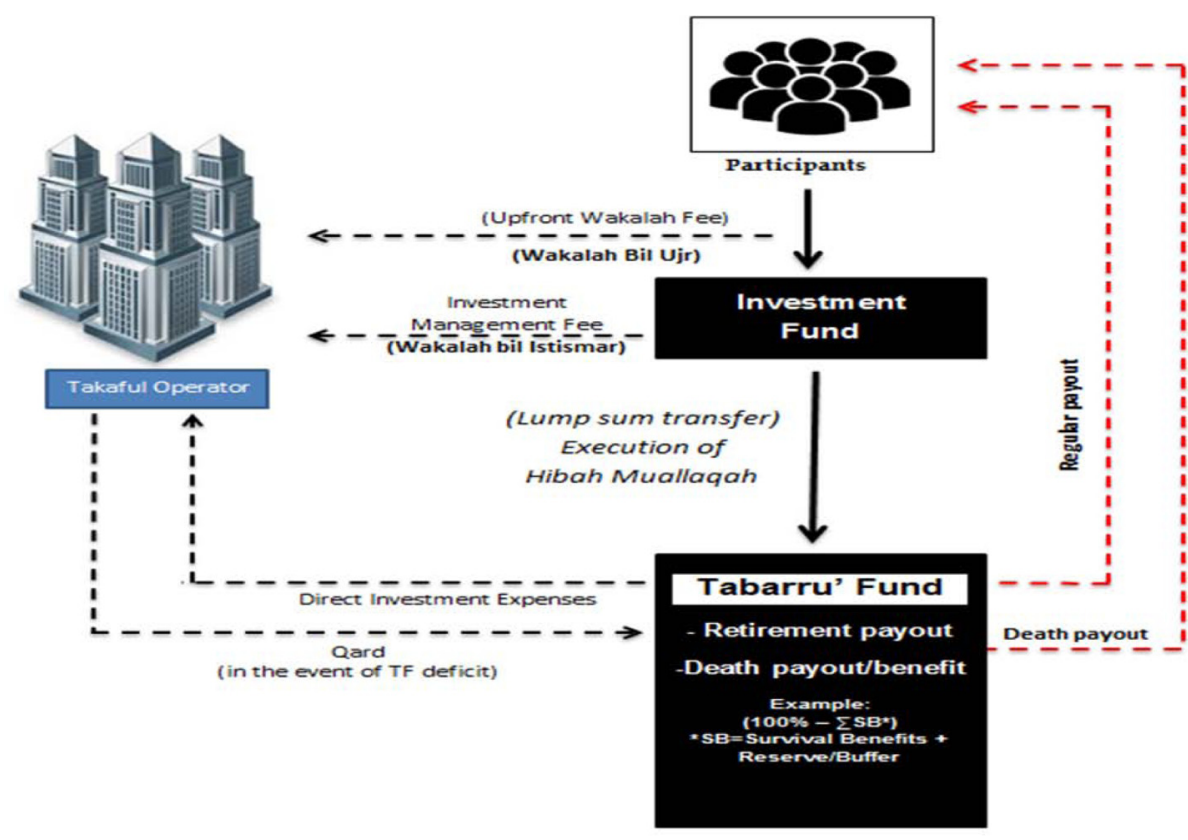

Source: Based on concepts explicated in Ali et al. (2014)

\section{takāful \\ retirement annuity plan}

Figure 1. Proposed model for takāful annuity plan

- to compare the proposed takāful annuity product with similar retirement plans in Malaysia such as Government Pension Scheme, EPF and PRS; and

- to explore the possibility of relaunching the annuity retirement plan in Malaysia in view of the identified challenges.

\section{Methodology}

The research is qualitative in nature and uses three methodological instruments:

- literature review: review the main literature on annuities to identify the main challenges of takāful retirement plans;

- content analysis: analysis of the literature from Sharī'ah, legal and operational perspectives; and

- semi-structured interviews: identify the main challenges facing the development of a viable takaful annuity retirement plan in Malaysia and the way forward.

\section{Challenges of introducing takāful annuity plan in Malaysia}

From the practices of takâful annuity in Malaysia as well as some research outputs conducted on the feasibility of the proposed product, there is a need to assess the cited challenges of the proposed product and zoom in on the real challenges hindering the development of takâful annuities in Malaysia. The present research focuses on operational 
challenges in view of previous practices and input from industry players as well as research findings on annuities in Malaysia. Preliminary challenges found are the following:

- Insufficient sukūk instruments that can be used in the accumulation stage of the annuity product. This is based on statistics that showed that the number of long-term sukūk (20 to 30 years' maturity) and perpetual șukūk are dwindling, which makes it difficult to develop an annuity product that guarantees a stream of payments from retirement till death of the annuitant.

- Downsizing of the șukuk market as a result of șukūk under-rating and possible default events.

- The majority of șukuk are redeemed long before maturity, a factor that would affect the expected returns on șukuk, jeopardizing the long-term payouts during retirement.

- The challenge of longevity risk as people are living longer due to improved living conditions and health care programmes. This would mean that the regular payouts of the annuities would have to undergo a harmonization of assets and liabilities to avoid paying more annuities for longer lives (asset-liability mismatch).

- The deficit of the annuity fund and the operational aspect of qard (loan) injection and its repayment. As depicted in Figure 1, in the event of deficit, the takâful operator provides qard to the tabarru' fund. This may be seen as a capital guarantee on its part, as it is merely a wakil (trustee) not a guarantor during the accumulation period. If the qard is injected into the tabarru' fund, then it would be difficult to justify the occurrence of the deficit if the payout is based on an "upon claim basis".

- $\mathrm{RBC}$ requirement makes takāful annuity products less affordable as the uncertainty featuring the longevity risk would require more allocation of capital with prices soaring beyond the affordability of annuitants.

- EPF is unlikely to accept any withdrawals by employees to contribute to the annuity scheme. Annuitants would have to find other sources to buy the product, which is practically very challenging in view of the scarcity of sources and strict regulations on pension schemes.

- The applicability of the Islamic Financial Services Act 2013 on the proposed takâful annuity plan has yet to be put to the test. The definition of a defined risk in a typical takāful arrangement versus a known event in an annuity may pose a Sharī'ah and legal issue as far as this product is concerned. Governance issues may arise as well.

\section{Conclusion}

The present study capitalizes on previous practices of takāful retirement plans and research conducted on takäful annuities in Malaysia. The research aims to identify the main challenges facing the development of such a product and the possibility of relaunching it by takâful operators in Malaysia. The preliminary findings of the research have unveiled a number of challenges that will be put to the test via content analysis and semi-structured interviews. Preliminary conclusions suggest that the takäful annuity product should have diversified investment portfolios both in terms of maturity and asset quality. Capitalization of annuities should be better regulated to reduce cost and price. Besides, outsourcing the contributions from funds such as EPF is not recommended in view of a șukuk market marred by uncertainty and scarcity of long-term șukūk instruments. 


\section{References}

Alhabshi, S.O., Sharif, K., Shaikh Abdul Razak, S.H. and Ismail, E. (2012), Takāful: Realities and Challenges, Pearson Malaysia Sdn Bhd, Petaling Jaya.

Ali, M.M., Hussain, L., Johari, A.H. and Zai, F.H. (2014), "Exploring a Shari'ah compliant model for retirement annuity plans”, ISRA Research Paper, no. 69/2014, International Shari'ah Research Academy for Islamic Finance (ISRA), Kuala Lumpur.

Ismail, F. (2017), "Islamic pensions: developing takāful retirement products", available at: www. menainsuranceceoclub.com/Article.aspx?id=13821 (accessed 22 February 2017).

Yusof, M.F., Wan Ismail, W.Z. and Mohd Naaim, A.K. (2011), Fundamentals of Takāful, IBFIM, Kuala Lumpur.

\section{Further reading}

Kassim, Z.A.M. (2015), Challenges of Developing Annuity Schemes for Takāful Providers, Powerpoint presentation.

\footnotetext{
About the author

Younes Soualhi, $\mathrm{PhD}$, is a Senior Researcher at the International Shari'ah Research Academy for Islamic Finance (ISRA), Kuala Lumpur, Malaysia. He holds a master's degree and $\mathrm{PhD}$ in Sharī'ah. His research interests are in the areas of figh al-mu'amalat, takâful, Islamic banking and the Islamic capital market. Younes Soualhi can be contacted at: younes@isra.my
}

For instructions on how to order reprints of this article, please visit our website: www.emeraldgrouppublishing.com/licensing/reprints.htm Or contact us for further details: permissions@emeraldinsight.com 